\title{
DIGESTION, N-UTILIZATION AND PERFORMANCE OF LACTATING COWS FED CHEMICALLY OR/AND BIOLOGICALLY TREATED FLAX STRAW
}

\author{
H.M. El-Gendy ${ }^{1}$, M.E.R. Hammad ${ }^{1}$, M.H.M. Yacout ${ }^{2}$ and A.M.A. El- \\ Hais $^{1}$
}

1-Department of Animal Production, Faculty of Agriculture, Tanta University, (Tanta), 2- Animal Production Institute, Agriculture Research Center, Minister of Agriculture

\section{SUMMARY}

This study was carried out at Noubaria Experimental Station, Animal Production Research Institute, Ministry of Agriculture and Faculty of Agriculture (Tanta), Tanta University. Six male adult Barki sheep $(42 \mathrm{~kg} \pm 1.5 \mathrm{~kg})$, three each group were used for digestibility trails. Four lactating cows were arranged in $4 \times 4$ Latin square to carry out the lactation experiment. Animals were fed experimental diets containing

1. Flax straw without (FS).

2. Flax straw treated with urea at $4 \%$ on DM basis, (UFS).

3. Flax straw treated with Trichodema viride (FFS).

4. Flax straw treated with urea and Trichodema viride (UFFS).

The results explained that, $F S$ treatment had significant effect on digestibilities of $D M(P<0.0003), O M(P<0.0001), C F$ and $C P(P<0.0004)$, and $E E(P<0.036)$, while no significant effect was detected for NFE. Sheep fed diet containing UFFS showed higher $(P<0.0001)$ digestibility of NDF and cellulose followed by those fed FFS containing diet without significant differences. But they had higher $(P<0.0001)$ digestibility of ADL and hemicellulose compared to other diets. While, those fed FFS containing diet, had the highest $(p<0.0001)$ digestibility of ADF (39.76\%). Treatments of flax straw had no significant effect on dry matter intake (DMI). But, it had significant effect $(P<0.0001)$ on $N B$ and biological value of $N(N B / A N)$. Diet of UFFS was more effective for increasing $N$-utilization of experimental diets and feeding value expressed as TDN $(P<0.0001)$ and DCP $(P<0.0007)$. Diet of UFFS increased milk yield and yields of milk fat, milk protein and $4 \%$ (FCM) yields. No significant influences were observed for milk lactose, SNF, TP, and ash while increased $(P<0.0018)$ milk TS and fat $(\%)$. Treatments of FS had no harmful effects on blood patterns. UFFS diet showed the best economic feed efficiency followed by FFS, FS and UFS diets. It can be concluded from this study that, treatments with urea followed by fungus (T. viride) treatment could be promising for utilization straw for sheep and dairy cows.

Keywords: Digestion, $\mathrm{N}$-utilization, performance, lactating cows, flax straw

\section{INTRODUCTION}

The digestibility of most of roughages, especially straws, is often low because they have high crude fiber. Generally, cereal straws as wheat, rice, barley, and oat

Issued by The Egyptian Society of Animal Production 
straws are the most crop residues used for livestock nutrition. Nowadays, flax straw appeared in the surface as its abundant by-products of oil seed flax industry and available in a large quantity (31,000 tons/year in Egypt, ARC, 2004).In the same time, few trails were conducted to enhance the availability of flax straw for ruminants feeding by treatments such as ammoniation and supplemented with barley grain for beef cattle (Mann et al., 1988). Also, it was tried to fed ammoniated flax straw with sweet clover hay for sheep (Howard et al., 1991). Many studies have been done to enhance the utilization of crop residues of cereal and legumes using pre-treatment methods. Urea treatment may be used to optimize the utilization of low quality straws by increasing rumen $\mathrm{N}$ which led to promote microbial protein synthesis, (Bebe and Flex, 1996).Recently, biological treatment especially, fungal treatment is expected to make mutation in future for fermentation technology and alternative enzyme production systems (Beauchemin et al., 2004). Also, other studies indicated that, biochemical treatment may be useful for increasing availability of straws as ruminant feeds. ( Eun et al., 2006) indicated that, there was a synergistic effect between ammonia pre-treatment and exogenous enzymes derived from fungi (Trichoderma viride).The synergy may indicate that ammoniation remove phenolic compounds and disrupt the lignin carbohydrate complex, therapy increasing the accessibility of straws to enzymatic action. In meantime, the higher cost of the concentrate led to the scientists to find out new resources in order to solve part of such situation. So, the aim of this study is to evaluate the use of flax straw as one of untraditional agricultural byproducts, and to find out the effect of urea treatment, biological treatment using the fungus Trichoderma viride, and their combination on chemical composition, cell wall degradation, and N-utilization in sheep fed flax straw diets. Blood picture and milk production by dairy cattle fed the same straw are also studied and economical efficiency of using such straw considered as well.

\section{MATERIALS AND METHODS}

This study was conducted at Noubaria Experimental Station, Animal Production Research Institute, Ministry of Agriculture and Faculty of Agriculture(Tanta), Tanta University. Urea treatment was conducted by spraying two stacks of chopped flax straw (2-3 cm length) with 4\% urea solution ( $100 \mathrm{~kg}$, weight/ 4 litre,volume on DM basis). After spraying, flax straw was covered with a plastic sheet and stored for 28 days (during October to February) as reaction period, then the plastic sheet was taken off from one stack and treated flax straw was left for 3 days for aeration (Chauhan, 1982). The second stack was treated with the fungus (Trichoderma viride. The Trichoderma viride) as explained by Gupta, 1988 (the fungus was grown and maintained on corn meal agar and incubating at 34 to $37^{\circ} \mathrm{C}$ for 28 days), in order to combine chemical with biological treatment.

Untreated or treated flax straw was offered to animals ad-libitum as roughage in four diets, untreated flax straw (FS)as a control and treated flax straw with $4 \%$ urea (UFS), fungus (Trichoderma viride, FFS), and urea, then with the fungus, Trichoderma viride (UFFS). While, concentrate feed mixture (CFM) was offered at 9 $\mathrm{kg}$, according to NRC (1985) for sheep. Chemical analysis of the experimental diets and CFM were presented in Table (1). Six adult Barki male sheep (42 $\pm 1.5 \mathrm{~kg})$ were used to conduct the digestibility trails, in order to evaluating the nitrogen utilization, 
and feeding values. The digestibility trails lasted about 21 days as preliminary period, followed by 7 days as a collection period. The animals were kept in individual cages and fed the experimental diets and water was available all the time. Feed, refusal feed and faces were analyzed according to method of A.O.A.C. (1984). The cell wall constituents as NDF, ADF and ADL were estimated according to Goering and Van Soest (1979). Four Frisian cattle, (weighted 500 to $550 \mathrm{~kg} \mathrm{LBW}$ ) were used in 4 x 4 Latin square design to study the effect of treated flax straw in lactating cows diets on milk production, milk composition and blood picture. The experiment was started after 5 weeks of the calving and lasted about 4 weeks. Flax straw was offered adlibitum to animals and CFM (concentrate feed mixture) was offered according to NRC (1988). Drinking water was available all the time. Daily milk production was recorded once a week for each cow. The morning milk samples immediately cooled. Total solids (TS) were determined by weighting after drying at $110^{\circ} \mathrm{C}$ for 3 to $4 \mathrm{hrs}$ till fixed weight. Milk fat was determined according to Gerber's methods described by Ling (1963) and solid not fat (SNF) was calculated by the difference. Fat corrected milk (FCM, 4\%) was calculated according to Gaines (1923) using the following equation:

$$
\mathrm{FCM}=0.4 \mathrm{M}+15.0 \mathrm{~F} \quad \text { Where } \mathrm{M}=\text { milk yield, } \quad \mathrm{F}=\text { fat yield }
$$

Table 1. Chemical analysis of the experimental roughages and CFM on DM basis

\begin{tabular}{|c|c|c|c|c|c|}
\hline Diets & FS & UFS & FFS & UFFS & CFM \\
\hline \multicolumn{6}{|l|}{ Nutrients } \\
\hline Dry matter (DM) & 89.33 & 88.63 & 89.06 & 88.86 & 88.14 \\
\hline Organic matter (OM) & 81.84 & 80.46 & 79.64 & 78.33 & 91.9 \\
\hline Crude protein $(\mathrm{CP})$ & 3.03 & 7.61 & 8.68 & 9.82 & 15.39 \\
\hline Crude fiber $(\mathrm{CF})$ & 46.27 & 38.17 & 36.84 & 35.13 & 6.52 \\
\hline Ether extract (EE) & 0.63 & 0.60 & 0.73 & 0.66 & 3.29 \\
\hline Ash & 18.16 & 19.54 & 20.36 & 21.67 & 8.10 \\
\hline Nitrogen free extract (NFE) & 31.91 & 34.08 & 33.39 & 32.72 & 66.7 \\
\hline \multicolumn{6}{|l|}{ Cell wall constituents } \\
\hline \multirow{2}{*}{$\begin{array}{ll}\text { Neutral detergent } & \text { fiber } \\
\text { (NDF) } & \end{array}$} & 81.21 & 75.66 & 73.18 & 68.35 & 17.12 \\
\hline & 58.35 & 56.17 & 53.22 & 50.09 & 12.36 \\
\hline Acid detergent fiber(ADF) & 19.63 & 18.45 & 18.11 & 17.23 & 1.38 \\
\hline \multirow{2}{*}{$\begin{array}{l}\text { Acid detergent lignin } \\
(\mathrm{ADL})\end{array}$} & 22.86 & 19.49 & 19.26 & 18.26 & 4.76 \\
\hline & 38.72 & 37.72 & 35.11 & 32.86 & 10.98 \\
\hline \multicolumn{6}{|l|}{ Hemicellulose } \\
\hline \multicolumn{6}{|l|}{ Cellulose } \\
\hline \\
\hline & & \\
\hline \multirow{2}{*}{\multicolumn{5}{|c|}{$\begin{array}{l}\text { FFS } \\
\text { FFS } \\
\text { Flax straw treated with urea diet. } \\
\text { UFFS }\end{array}$}} & \\
\hline & & & & & \\
\hline \multicolumn{6}{|l|}{ CFM Concentrate feed mixture } \\
\hline
\end{tabular}


Blood samples were taken from each cow at weekly intervals then were stored at $-20^{\circ} \mathrm{C}$ until subsequent analysis for hemoglobin and some other plasma patterns contained total protein albumin, globulin, aspartic amine transaminase (AST, GOT), alanine amino transferase (ALT, GPT) and urea. Plasma was separated frozen and. Plasma protein, albumin, AST and ALT were estimated by spectrophotometer using commercial kites. Data were statistically analyzed using procedure of SAS (2000). Duncan's Multiple Range Test (Duncan, 1955) was used to compare among means of each trait.

\section{RESULTS AND DISCUSSION}

\section{Digestibility and cell wall composition:}

A significant increase $(\mathrm{P}<0.05)$ of all nutrients, NDF and cellulose digestibility coefficient, (except for NFE) was observed when experimental animals fed on different treated FS (Table 2). However, both fungi treatments were showed the highest nutrients digestibility values than those of the other diets. No significant difference was observed between sheep fed untreated or treated FS with urea for DM and EE digestibilities. Sheep fed diet contained UFFS had higher $(\mathrm{P}<0.0001)$ digestibility for ADL and hemicellulose than those fed on the other diets, but it had less $(\mathrm{P}<0.0001)$ digestibility of ADF compared to those fed on FFS . Feeding values expressed as TDN and DCP were high $(\mathrm{P}<0.0001$ and $\mathrm{P}<0.0001$, respectively) in diets contained FFS and UFFS compared to the other diets. Lower nutritive values were recorded for sheep fed diets contained untreated FS. The mechanism by which alkali treatment improved the efficacy of enzymes for enhancing feed digestion remains unknown, but it could be suggested that, removal of the phenolic barriers that impede the microbial digestion of the feed may be involved (Wang et al., 2001). Rai et al. (1989) reported that, applying exogenous fibrolytic enzymes (EFE) onto untreated straw had no significant effects on digestion while, Rode et al. (1999) found that, fibrolytic enzymes (FE) produced by fungus significantly increased DM, OM, $\mathrm{NDF}$, ADF, and CP digestibility by dairy cows . Treating feeds with fungus may improve digestibility via a number of different mechanism including, direct hydrolysis, enhanced microbial attachment, changes in viscosity, complementary actions with ruminal enzymes, and changes in the site of nutrient digestion (Beauchemin et al., 1998). The superiority of most digestibility coefficient of nutrients for especially, NDF, ADF, and cellulose, as well nitrogen utilization showed for sheep fed diets containing UFFS compared with untreated straw, suggesting a synergistic effect of urea pre-treatment and EFE application through fungi on microbial activity in the rumen. This suggestion probably arises from the combination of the alkali-mediated removal of structural barriers to rumen microbial colonization and exogenous fibrolytic enzymes (EFE) mediated greater availability of soluble sugars for microbial growth (Wang et al., 2004). 
Table 2. Effect of the experimental diets on the nutrients digestibility coefficients

\begin{tabular}{lcccc}
\hline \multicolumn{1}{c}{ Diets } & FS & UFS & FFS & UFFS \\
Digestibility & & & & \\
\hline & & & & \\
DM & $58.40 \pm 1.30^{\mathrm{b}}$ & $60.46 \pm 0.37^{\mathrm{b}}$ & $66.94 \pm 0.21^{\mathrm{a}}$ & $67.48 \pm 0.29^{\mathrm{a}}$ \\
OM & $62.65 \pm 0.91^{\mathrm{c}}$ & $67.27 \pm 0.18^{\mathrm{b}}$ & $70.27 \pm 0.10^{\mathrm{a}}$ & $71.94 \pm 0.13^{\mathrm{a}}$ \\
$\mathrm{CP}$ & $48.90 \pm 2.46^{\mathrm{c}}$ & $55.29 \pm 0.71^{\mathrm{b}}$ & $61.62 \pm 0.21^{\mathrm{a}}$ & $62.14 \pm 1.33^{\mathrm{a}}$ \\
$\mathrm{CF}$ & $30.45 \pm 2.29^{\mathrm{c}}$ & $36.45 \pm 0.14^{\mathrm{b}}$ & $48.16 \pm 1.60^{\mathrm{a}}$ & $50.36 \pm 1.03^{\mathrm{a}}$ \\
EE & $79.93 \pm 1.27^{\mathrm{b}}$ & $83.14 \pm 0.10^{\mathrm{ab}}$ & $84.84 \pm 0.60^{\mathrm{a}}$ & $85.63 \pm 0.38^{\mathrm{a}}$ \\
NFE & $78.19 \pm 0.98^{\mathrm{a}}$ & $78.29 \pm 0.47$ & $78.39 \pm 0.02^{\mathrm{a}}$ & $80.06 \pm 0.22^{\mathrm{a}}$ \\
NDF & $20.93 \pm 0.03^{\mathrm{c}}$ & $27.03 \pm 0.09^{\mathrm{b}}$ & $38.67 \pm 0.02^{\mathrm{a}}$ & $38.82 \pm 0.01^{\mathrm{a}}$ \\
ADF & $19.74 \pm 0.08^{\mathrm{d}}$ & $28.24 \pm 0.02^{\mathrm{b}}$ & $39.76 \pm 0.02^{\mathrm{a}}$ & $25.83 \pm 0.04^{\mathrm{c}}$ \\
ADL & $23.27 \pm 0.03^{\mathrm{d}}$ & $30.91 \pm 0.02^{\mathrm{c}}$ & $43.21 \pm 0.01^{\mathrm{b}}$ & $47.08 \pm 0.01^{\mathrm{a}}$ \\
Hemicellulose & $18.78 \pm 0.02^{\mathrm{d}}$ & $23.72 \pm 0.02^{\mathrm{c}}$ & $36.93 \pm 0.04^{\mathrm{b}}$ & $37.13 \pm 0.01^{\mathrm{a}}$ \\
Cellulose & $17.92 \pm 0.03^{\mathrm{c}}$ & $36.96 \pm 0.02^{\mathrm{b}}$ & $38.00 \pm 1.15^{\mathrm{a}}$ & $36.65 \pm 0.02^{\mathrm{a}}$ \\
TDN (\%) & $58.01 \pm 0.56^{\mathrm{c}}$ & $62.01 \pm 0.06^{\mathrm{b}}$ & $64.51 \pm 0.06^{\mathrm{a}}$ & $65.38 \pm 0.1^{\mathrm{a}}$ \\
DCP (gm/day) & $5.62 \pm 0.38^{\mathrm{c}}$ & $7.19 \pm 0.06^{\mathrm{b}}$ & $8.14 \pm 0.60^{\mathrm{a}}$ & $8.39 \pm 0.19^{\mathrm{a}}$
\end{tabular}

$\mathrm{a}, \mathrm{b}, \mathrm{c}$ and $\mathrm{d}$ means in the same raw with no common superscript are significantly different $(\mathrm{P}<0.05)$.

\section{Nitrogen utilization:}

Higher $(\mathrm{P}<0.0001)$ nitrogen intake $(\mathrm{NI})$ was noticed for sheep fed diets contained either FFS or UFFS, followed by those fed UFS (Table 3$)$. The lowest $(\mathrm{P}<0.0001) \mathrm{NI}$ was showed by untreated FS. All sheep fed the experimental diets had positive nitrogen balance $(\mathrm{NB})$ The highest $(\mathrm{P}<0.0001) \mathrm{NB}$ value was obtained by sheep fed diets contained UFFS, followed by those fed on FFS, then UFS and FS diets, respectively. he pervious results may be explained that, treatment with fungi allow some kind of applying enzymes to feed in this fashion, binding the enzyme to the substrate and may result in a conformational change that makes the enzymes more resistance to proteolysis. This approach offers exciting possibilities for using enzymes to improve nutrient digestion, N-utilization, and the same time, reduce animal fecal (Kung et al., 2000).

Table 3. Effect of the experimental diets on nitrogen-utilization by sheep

\begin{tabular}{|c|c|c|c|c|}
\hline Items & FS & UFS & FFS & UFFS \\
\hline Dry matter intake (DMI) & $1264.64 \pm 37.62$ & $1209.29 \pm 5.56$ & $1226.63 \pm 4.07$ & $1229.72 \pm 3.96$ \\
\hline Nitrogen intake (NI) & $23.10 \pm 0.40^{\mathrm{c}}$ & $25.14 \pm 0.04^{b}$ & $25.91 \pm 0.01^{\mathrm{a}}$ & $26.57 \pm 0.04^{\mathrm{a}}$ \\
\hline Nitrogen balance (NB) & $4.08 \pm 0.42^{\mathrm{d}}$ & $5.29 \pm 0.10^{\mathrm{c}}$ & $6.94 \pm 0.19^{b}$ & $8.52 \pm 0.16^{\mathrm{a}}$ \\
\hline Absorbed nitrogen (AN) & $11.29 \pm 0.53^{\mathrm{c}}$ & $13.90 \pm 0.10^{b}$ & $15.97 \pm 0.06^{\mathrm{a}}$ & $16.51 \pm 0.37^{\mathrm{a}}$ \\
\hline $\mathrm{NB} / \mathrm{NI}$ & $19.39 \pm 0.67^{\mathrm{c}}$ & $21.06 \pm 0.36^{\mathrm{c}}$ & $26.80 \pm 0.74^{b}$ & $32.07 \pm 0.63^{\mathrm{a}}$ \\
\hline NB/AN (Biological value) & $39.64 \pm 1.04^{\mathrm{c}}$ & $38.11 \pm 0.99^{\mathrm{c}}$ & $43.47 \pm 1.06^{\mathrm{b}}$ & $51.61 \pm 1.17^{\mathrm{a}}$ \\
\hline
\end{tabular}

$\mathrm{a}, \mathrm{b}, \mathrm{c}$ and $\mathrm{d}$ means in the same raw no common superscript are significantly different $(\mathrm{P}<0.05)$.

\section{Lactation experiment:}


There were no significant effects when treated flax straw was fed to lactating cows on milk lactose, SNF, TN, and ash (Table 4), however significant influences were observed for milk TS $(\mathrm{P}<0.0001)$ and milk fat $(\mathrm{P}<0.0018)$. Animal fed on FFS diet had the highest milk TS value while, those fed on UFFS diet had a higher milk fat, while FS had lower milk TS and milk fat (11.73 vs. $11.57 \%$ and 3.41 vs. $3.26 \%)$. Treated flax straw with fungus significantly $(\mathrm{P}<0.0001)$ enhanced milk yield, 4\% FCM, fat and protein yields. Treating feeds with EFE improved cow's performance (Schingoethe et al., 1999; Beauchemin et al., 2004). For example, Stokes and Zheng, 1995, reported that, using enzymes on forage increased DMI by $10.7 \%$ and milk yield by $14.2 \%$. In this study milk yield was increased by $20 \%$ for treatment of FS with urea than with the fungus, while the increase was only $9.8 \%$ for the fungus treatment, compared with the untreated FS.

Table 4. Effect of the experimental diets on milk yield and milk composition

\begin{tabular}{|c|c|c|c|c|}
\hline Items & FS & UFS & FFS & UFFS \\
\hline \multicolumn{5}{|l|}{ Yields (kg / week) } \\
\hline Milk yield ( Kg) & $12.66 \pm 3.310^{\mathrm{c}}$ & $12.73 \pm 2.060^{c}$ & $13.90 \pm 2.527^{\mathrm{b}}$ & $15.36 \pm 2.48^{\mathrm{a}}$ \\
\hline Fat yield $(\mathrm{Kg})$ & $0.41 \pm 0.120^{\mathrm{c}}$ & $0.43 \pm 0.101^{b c}$ & $0.47 \pm 0.115^{b}$ & $0.52 \pm 0.0121^{a}$ \\
\hline Protein yield(Kg) & $0.42 \pm 0.100^{\mathrm{c}}$ & $0.42 \pm 0.079^{\mathrm{c}}$ & $0.46 \pm 0.086^{b}$ & $0.51 \pm 0.096^{\mathrm{a}}$ \\
\hline $\operatorname{FCM}(4 \%)$ & $15.37 \pm 4.208^{c}$ & $15.79 \pm 3.23^{c}$ & $17.36 \pm 3.23^{b}$ & $19.11 \pm 3.95^{\mathrm{a}}$ \\
\hline \multicolumn{5}{|l|}{ Milk composition } \\
\hline Lactose & $4.02 \pm 0.082$ & $4.02 \pm 0.900$ & $4.036 \pm 0.098$ & $3.97 \pm 0.117$ \\
\hline TS & $11.57 \pm 0.055^{\mathrm{c}}$ & $11.62 \pm 0.057^{b c}$ & $11.73 \pm 0.061^{\mathrm{a}}$ & $11.70 \pm 0.064^{\mathrm{ab}}$ \\
\hline SNF & $8.32 \pm 0.071$ & $8.34 \pm 0.059$ & $8.38 \pm 0.067$ & $8.29 \pm 0.068$ \\
\hline Fat & $3.26 \pm 0.064^{\mathrm{c}}$ & $3.29 \pm 0.053^{b c}$ & $3.34 \pm 0.066^{\mathrm{ab}}$ & $3.41 \pm 0.071^{\mathrm{a}}$ \\
\hline $\mathrm{TP}$ & $3.30 \pm 0.034$ & $3.30 \pm 0.032$ & $3.34 \pm 0.038$ & $3.32 \pm 0.037$ \\
\hline Ash & $0.99 \pm 0.015$ & $1.01 \pm 0.020$ & $1.01 \pm 0.030$ & $1.00 \pm 0.034$ \\
\hline $\begin{array}{l}\text { a,b,c and } d \text { means in } t \\
\text { T S Total solids } \\
\text { SNF Solid not fat } \\
\text { TN Total }- \text { N } \\
\text { FCM Fat-corrected }\end{array}$ & me raw no common & uperscript are sign & cantly different ( $\mathrm{P}$ & $.05)$. \\
\hline
\end{tabular}

\section{Blood parameters:}

Biological or/and chemical treatment had a significant influence $(\mathrm{P}<0.0001)$ on blood patterns determined as TP, globulin, albumin, A/G , urea, AST, and ALT (Table 5). Cows fed urea-treated FS diet had a higher activity of kidney as a result of increasing blood urea, AST, and ALT compared with other experimental diets fed to cows. The same trend was found by urea treatment for blood globulin, while blood TP was higher with urea and fungus treatment. On the other hand, blood albumin and $\mathrm{A} / \mathrm{G}$ were higher with fungi treatment. Generally, blood patterns were within the normal range when experimental diets fed to cows (Fouad et al., 1998, Gaines, 1923, and Ibrahim, 2001).

\section{Economic feed efficiency:}

Feeding experimental diets to lactating cows showed that, daily feed cost and average of daily milk yield were more with UFFS diet followed by FFS, UFS, and FS diets (Table 6). A similar trend was achieved with UFFS diet as average return of 
milk yield. Generally, UFFS diet had more economic efficiency followed by FFS, FS, and UFS $(235.08,226.14,217.28$, and $208.39 \%$, respectively).

Table 5. Effect of experimental diets on blood parameters of lactating cows

\begin{tabular}{lllll}
\multicolumn{1}{c}{ Diets } & FS & UFS & FFS & UFFS \\
Items & & & \\
\hline TP $(\mathrm{g} / 100 \mathrm{ml})$ & $6.90 \pm 0.01^{\mathrm{c}}$ & $7.96 \pm 0.02^{\mathrm{b}}$ & $7.70 \pm 0.01_{\mathrm{b}}$ & $7.80 \pm 0.09^{\mathrm{a}}$ \\
Globulin $(\mathrm{g} / 100 \mathrm{ml})$ & $3.77 \pm 0.73^{\mathrm{d}}$ & $4.70 \pm 0.04^{\mathrm{a}}$ & $3.96 \pm 0.01^{\mathrm{c}}$ & $4.10 \pm 0.05^{\mathrm{b}}$ \\
Albumin $(\mathrm{g} / 100 \mathrm{ml})$ & $3.14 \pm 0.03^{\mathrm{c}}$ & $3.42 \pm 0.02^{\mathrm{b}}$ & $3.75 \pm 0.01^{\mathrm{a}}$ & $3.68 \pm 0.01^{\mathrm{a}}$ \\
A/G $(\%)$ & $0.85 \pm 0.12^{\mathrm{b}}$ & $0.81 \pm 0.01^{\mathrm{b}}$ & $0.94 \pm 0.01^{\mathrm{a}}$ & $0.91 \pm 0.14^{\mathrm{a}}$ \\
Urea $(\mathrm{g} / 100 \mathrm{ml})$ & $36.71 \pm 0.16^{\mathrm{d}}$ & $40.87 \pm 0.09^{\mathrm{a}}$ & $38.50 \pm 0.17^{\mathrm{c}}$ & $39.93 \pm 0.01^{\mathrm{b}}$ \\
AST $(\mathrm{U} / \mathrm{L})$ & $61.94 \pm 0.11^{\mathrm{d}}$ & $66.78 \pm 0.14^{\mathrm{a}}$ & $65.35 \pm 0.19^{\mathrm{c}}$ & $65.84 \pm 0.12^{\mathrm{b}}$ \\
ALT $(\mathrm{U} / \mathrm{L})$ & $16.55 \pm 0.14^{\mathrm{c}}$ & $18.71 \pm 0.04^{\mathrm{a}}$ & $18.51 \pm 0.15 \mathrm{a}$ & $18.04 \pm 0.09^{\mathrm{b}}$ \\
\hline a,b,c and d means in the same raw no common superscript are significantly different & $(\mathrm{P}<0.05)$. \\
TP Total protein & & & \\
A/G Albumin/globulin & & & \\
AST Aspartic amine transaminase enzyme &
\end{tabular}

Table 6. Effect of the experimental diets on economic feed efficiency of the experimental lactating cows

\begin{tabular}{|c|c|c|c|c|}
\hline $\begin{array}{ll}\text { Diets } \\
\text { Items }\end{array}$ & FS & UFS & FFS & UFFS \\
\hline \multicolumn{5}{|l|}{ Feed intake } \\
\hline$\overline{\mathrm{CFM}}$ & 9 & 9 & 9 & 9 \\
\hline Roughage(Flax straw) & 4.28 & 4.97 & 5.09 & 5.74 \\
\hline Total daily feed cost (L.E) & 8.74 & 9.18 & 9.22 & 9.75 \\
\hline Average daily milk yield $(\mathrm{kg} / \mathrm{d})$ & 12.66 & 12.75 & 13.90 & 15.28 \\
\hline Price of daily milk yield (L.E) & 18.99 & 19.13 & 20.85 & 22.92 \\
\hline Cash return & 10.25 & 9.95 & 11.63 & 13.17 \\
\hline
\end{tabular}

\section{CONCLUSION}

It can be concluded from this study that, treatment of flax straw with urea followed by fungus ( $T$. viride) treatment was found to be the most economic promising in order to have good utilizing of flax straw .

So, it could be advice to treat flax straw with urea then Trichoderma viride without harmful effect on rumen function and performance of sheep.

\section{REFERENCES}

A.O.A.C., 1984. Official Methods of Analysis $14^{\text {th }}$ Ed.. Association of Official Agriculture Chemists. Washington, D.C.A.R.C. 2004. Agricultural Research Center. Production of fibrous crops, Egypt. 
Bebe, F.N. and A. Flex, 1996. Growth performance of beef calves fed maize or sweet sorghum silages treated with urea or ammonia hydroxide. Tropical Agriculture. 731: 1-5.

Beauchemin, K.A., D.O. Colombatto, D.P. Morgavi and W.Z. Yang, 2004. Use of exogenous fibrolytic enzymes to improve feed utilization by ruminants. J. Anim. Sci. 812: E37-E47.

Beauchemin, K.A.; L. M. Rhode, W. Z. Yang and T. A. McAllister, 1998.Use of feed enzymes in ruminant nutrition. Pages 135 in Proc. Pacific Northest Anim. Conf. Portland, OR.

Chauhan, S.S., 1982. Effect of feeding urea treated straw supplemented with concentrate a fish meal on growth rate in heifers and its comparison with green sorghum. Proc. $3^{\text {rd }}$ Seminar, Bangladesh.

Duncan, D. B., 1995. Multiple ranges and multiple F test. Biometrics, 11:1.

Eun, J.S.; K.A. Beauchemin; S.H. Hong and M.W. Bauer 2006. Exogenous enzymes added to untreated or ammoniated rice straw: Effect on in vitro fermentation characteristics and degradability. Animal Feed. Sci. and Technology. 1: 16-22.

Fouad, R.T., A. Derez, and S.A. Ahia-Ismail, 1998. Biological versus urea treatment of roughages for sheep.J. Agric. Sci. Mansoura University, 23:103-106.

Gaines, W. L. 1923.Relation between percentages of fat content and yield of milk.1. Correction of milk yield for fat content. Agric. Exo. Sta. 245 C.F.Gaines. 1928

Goering, H.K. and J. Van Soest, 1979. Forage fibre analysis Agric. Hand Book No. 379.

Gupta, B. N.,1988. Development and concept of karnal process for fungal treatment of cereal straws. Pp. proc. Of intern workshop in fibrous crop residues as animal feeds. NDRI SRS Banglora.

Howard, M.D.; R.D.H. Cochen and J.A. Kernan, 1991. Effects of ammoniation and supplementing with sweet clover hay on intake and digestibility of flax straw by sheep. Can. J. Anim. Sci. 71:L 599-602.

Ibrahim, M. E., 2001. Effect of mechanical, chemical, and biological treatments of roughages on ruminal activity. Ph. D., Thesis, Fac, Agric. Cairo Univ.

Kung, L.J.R.; R.J. Treacher; G.A. Nauman; A.M. Sanagala; K.M. Endraes and M.A. Cohen, 2000. The effect of treating forages with fibrolytic enzymes on the nutritive value and lactation performance of dairy cows. J. Dairy Sci. 83: 115122.

Ling, E. R. ,1963. A text book of dairy chemistry. $3^{\text {th }}$ Ed. Vol, II. Chapman and Hall Ltd. London.

Mann, M. E., R. D .H. Cohn, A. A. Kernan, H. H. Nicholsen, D. A. Christan, and M.E. Smart ,1988. The feeding value of ammoniated flax straw, wheat straw and wheat chaff for beef cattle. Anim. Feed Sci. and technology. 21: 57-66.

N.R.C., 1985. National Research council. Nutrient Requirements of Sheep $6^{\text {th }}$ Ed.. National Academy Press, Washington, D.C. $6^{\text {th }}$ Rev. Ed.

N.R.C., 1988. National Research council. Nutrient Requirements of dairy cattle. National Research council Acad. Sci. Washington, DC, USA.

Rai, S.N.; T.K. Wali and B.N. Gupta, 1989. The chemical composition and nutritive value of rice straw after treatment with urea or Ocoprinus nology. 261-2: 81-92. 
Rhode, L. M., W. Z. Yang, and K. A. Beauchemin, 1999. Fibrolytic enzymes supplements for dairy cows in early lactation. J. Dairy Sci. 64:2121-2126.

SAS, USERS Guide: Statistics, 2000. Statistical analysis System Institute Inc., Gary , NC.

Schingoethe, D. J., G. A. Stegmen, and R. J. Treacher ,1999. Response of lactating dairy cows to a cellulose and xylanase enzyme mixture applied to forages at the time of feeding. J. Dairy Sci. 82:996-1003.

Stokes, M. R., and S. Zheng ,1995. The use of carbohydrase enzymes as feed additives for early lactation cows. Pag 35 in Proc. on Rumen Function. Chicago. IL.

Wang, Y.; B.M. Spratling; D.R. Zobell; R.D. Wiedmeier and T.A. Meallister ,2004. Effect of alkali pretreatment of wheat straw efficacy of exogenous fibrolytic enzymes. J Anim. Sci., 82:198-208.

Wang, Y., T. A. McAllister, L. M. Rhode, K. A. Beauchemin, and D. P. Mogavi, 2001. Effects on an exogenous enzyme preparation on microbial protein synthesis, enzyme activity and attachment to feed in the rumen stimulation. Technique Rusitec. 85:325-332. 
الهضم والاستفادة من النتروجين والاداء فى الابقارالحلابة المغذاة على تبن الكتان المعامل كيميائيا او بيولوجيا او بيوكيميائيا

حسن محمود الجندى'، محمد الفاتح رياض حماد'، محمد حلى محمد ياقوت"، عبد العزيز محمد عبد العزيز' - مبن مدود

1 - قسم الإنتاج الحيوانس، كلية الزراعة، جامعة طنطا، ب - معهج بحوث الإنتاج الحيوانس، وزلرة الزراعة

تم إجراء هذه التجربة في وحدة تجارب النوبارية وكلية الزراعة بطنطاو .استخدم في هذه التجربة أغنام البرقي

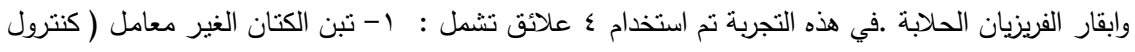

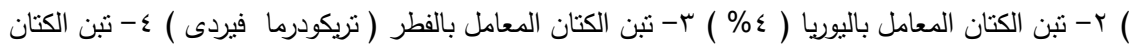

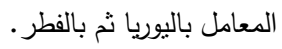

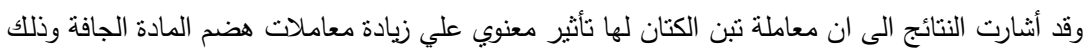

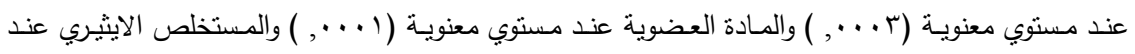

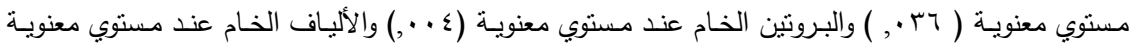

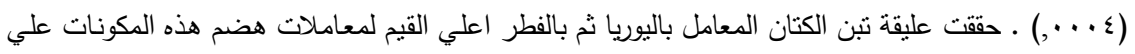

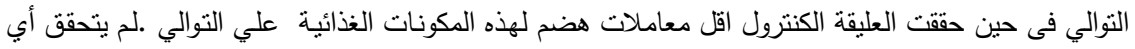

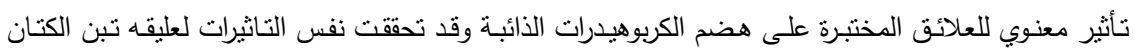

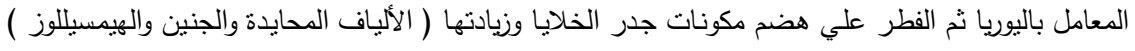

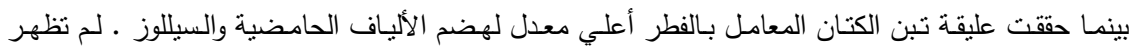

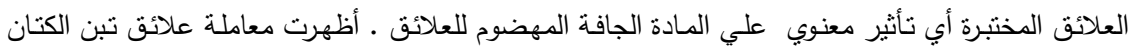

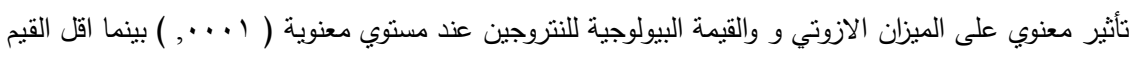

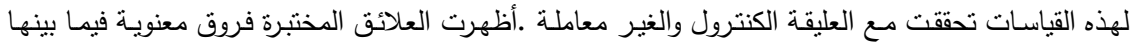

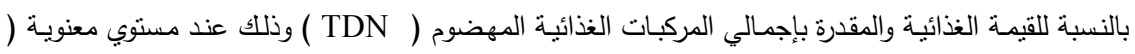

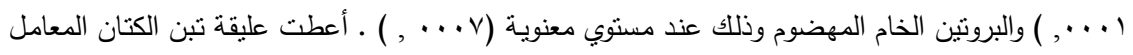

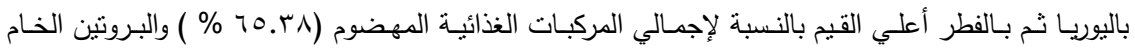

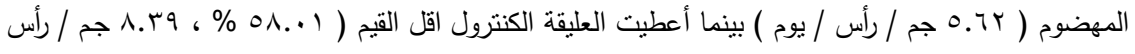

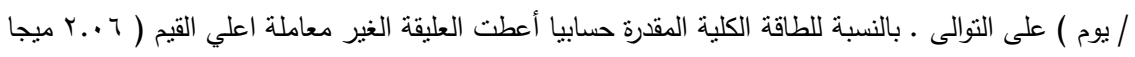

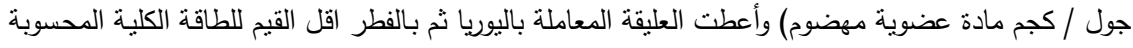

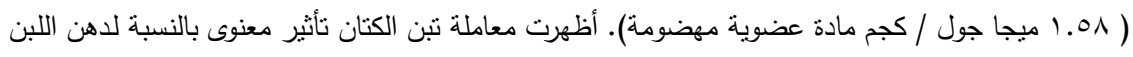

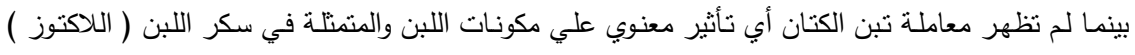

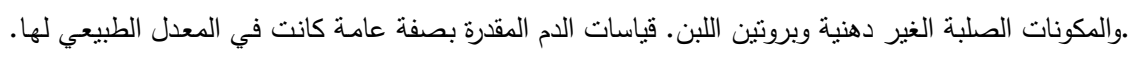
أثدارت النتائج إلي أن عليقة تبن الكتان المعامل باليوريا ثم بالفطر أعطت اعلي العيات عائد من إنتاج اللبن مابين 


$$
\begin{aligned}
& \text { العلائق المختبرة ـ كما أعطت نفس العليقة أفضل معدل استفاده اقتصادي يليها عليقة الفطر ثم العليقة الكنترول } \\
& \text { وفي النهاية العليقة المعاملة باليوريا . } \\
& \text { ونتيجة لذلك فيمكن التوصية باستخدام معاملة اليوريا ثم الفطر لتحسين كفاءة الاستفادة من تبن الكتان. }
\end{aligned}
$$

